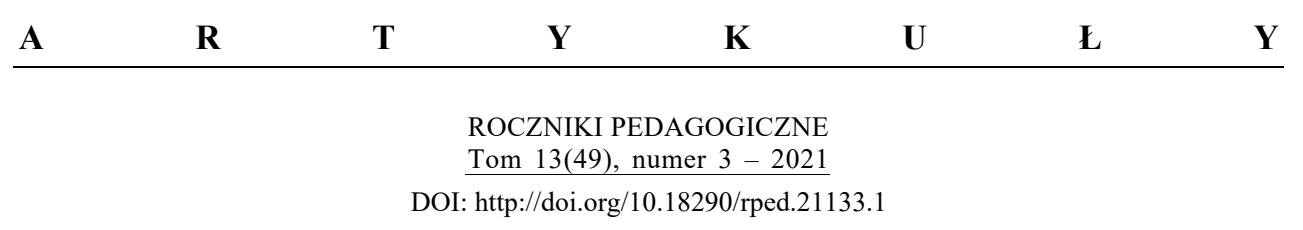

EWA DOMAGAŁA-ZYŚK

\title{
OSOBA CHORA I OSOBA Z NIEPEŁNOSPRAWNOŚCIĄ W RODZINIE W UJĘCIU TERESY KUKOŁOWICZ
}

\begin{abstract}
WSTĘP
W ciągu ostatnich dziesięcioleci w istotny sposób zmieniły się w Polsce postawy społeczne wobec osób chorych i osób z niepełnosprawnościami. Pisze o tym szczegółowo Z. Kazanowski (2011), wskazując na większą otwartość młodszych respondentów (licealistów) niż ich rodziców w odniesieniu do akceptacji aktywnej obecności osób z niepełnosprawnościami w przestrzeni publicznej. W kilku pierwszych dekadach XX wieku dominowały zachowania segregacyjne, zarówno $\mathrm{w}$ oficjalnych stanowiskach wyrażanych przepisami i rozporządzeniami, jak i w osobistych doświadczeniach względem dzieci, młodzieży i dorosłych z chorobami przewlekłymi, wadami i dysfunkcjami. Doświadczanie choroby lub niepełnosprawności przez jedną z osób w rodzinie często było powodem wstydu i wykluczenia, a słaba znajomość przyczyn zaburzeń w rozwoju wiązała się z pojmowaniem choroby i niepełnosprawności jako „kary za grzechy” czy też „fatum” doświadczającego rodzinę (por. np. Kawczyńska-Butrym 1992). W sytuacji stwierdzenia u dziecka rozwoju odbiegającego od normy niemal zawsze proponowano naukę w szkole specjalnej, często wbrew woli rodziców. Dość powszechnie akceptowaną praktyką było także - często wręcz zalecane przez lekarzy czy specjalistów - umieszczanie dzieci i starszych osób z chorobami przewlekłymi czy niepełnosprawnościami w całodobowych ośrodkach opiekuńczych, które

Dr hab. Ewa DomagaŁA-ZYŚK, prof. KUL - Katedra Pedagogiki Specjalnej, Instytut Pedagogiki, Wydział Nauk Społecznych Katolickiego Uniwersytetu Lubelskiego Jana Pawła II; adres do korespondencji: Al. Racławickie 14, 20-950 Lublin; e-mail: ewa.domagala-zysk@kul.pl; ORCID: https://orcid.org/0000-0002-2227-7102.
\end{abstract}


najczęściej znajdowały się $\mathrm{w}$ trudno dostępnych miejscach, poza terenem większych miast i wiosek. Opisane powyżej sytuacje należy oczywiście analizować w szerszym kontekście - ograniczonej wiedzy dotyczącej możliwości rozwojowych osób z niepełnosprawnościami i chorobami przewlekłymi oraz braku edukacyjnych placówek integracyjnych (które mogły być tworzone w Polsce dopiero po roku 1991, por. Bogucka, 1996; Domagała-Zyśk, Knopik, 2020). Konsekwencją jednak takiego segregacyjnego modelu leczenia i rehabilitacji był utrudniony kontakt rodziny z ich chorym czy niepełnosprawnym członkiem, co często owocowało zaburzeniami czy nawet zerwaniem wzajemnej relacji.

Doświadczenia i poglądy pedagogów, pracujących w tym okresie, stanowią kontekst, w jakim kształciły się dzieci i młodzież z niepełnosprawnościami i chorobami przewlekłymi. O ile współcześnie niektóre ich poglądy dotyczące społecznego kontekstu zdrowia i choroby (por. Kawczyńska-Butrym, 1984; Kirenko, 2007; Parczewska, 2012; Domagała-Zyśk, 2019) czy uznawania choroby i niepełnosprawności za czynnik wyzwalający wzrost osoby (por. Ogińska-Bulik, Juczyński, 2010; Byra, 2011; Byra, 2017) wydają nam się oczywiste i są przedmiotem pogłębionych analiz, o tyle kilkadziesiąt lat temu były nowatorskie i wyznaczały pewien innowacyjny model postaw wobec choroby i niepełnosprawności.

W tym kontekście profesor Teresa Kukołowicz powinna w większym zakresie niż obecnie zostać uznana za prekursorkę nowoczesnego stylu odniesienia względem osób chorych i niepełnosprawnych. Pracowała ona w Katolickim Uniwersytecie Lubelskim w latach 1959-2001, prowadząc badania i analizy naukowe, zwłaszcza na gruncie teorii wychowania i pedagogiki ogólnej. Jednocześnie wiele swoich tekstów poświęciła kwestiom związanym z pedagogiką rodziny oraz zagadnieniom choroby i roli człowieka chorego. Jest uznawana za prekursorkę socjologii medycyny. Już w roku 1971/ 1972 prowadziła w KUL wykład pt. „Socjologia medycyny” i był to pierwszy w Polsce wykład akademicki o takim profilu. Jako pierwsza w Polsce przygotowała także socjologiczną część podręcznika dla pielęgniarek (Kukołowicz, 1987), w którym zawarła swoją wizję roli pielęgniarki nie tylko jako osoby odpowiedzialnej za wykonywanie zabiegów medycznych, ale także za ułatwianie choremu kontaktu z rodziną i troskę o jego dobrostan społeczny i duchowy. T. Kukołowicz była współautorką programów nauczania dla średnich szkół medycznych, wygłaszała także wielogodzinne wykłady w Medycznym Studium Zawodowym w Lublinie, w Ośrodku Doskonalenia Średnich Kadr Medycznych, a także w Diecezjalnych Ośrodkach Pomocy Rodzinie. 
Na zlecenie Uniwersytetu Warszawskiego IPSiR, prowadziła m.in. temat badawczy: „Funkcjonowanie rodziny niepełnej i rodziny z dzieckiem upośledzonym". Jako Kierownik Sekcji Pedagogiki, a następnie Dyrektor Instytutu Pedagogiki zabiegała o obecność przedmiotów z zakresu pedagogiki specjalnej i pedagogiki dziecka chorego w programach studiów magisterskich z pedagogiki. Była także promotorem licznych prac magisterskich z zakresu pedagogiki leczniczej.

Teksty Profesor Teresy Kukołowicz publikowane były w różnych czasopismach i monografiach, w tym monografiach zbiorowych i nie są zdigitalizowane, co znacząco ogranicza dostęp do zawartych w nich treści. Celem niniejszego artykułu jest analiza wybranych tekstów Profesor Teresy Kukołowicz dotyczących jej nowatorskiego rozumienia funkcjonowania człowieka w sytuacji choroby i niepełnosprawności.

\section{ZNACZENIE RELACJI INTERPERSONALNYCH W PEDAGOGICE TERESY KUKOŁOWICZ}

Analizując wkład T. Kukołowicz we współczesne postrzeganie roli choroby i niepełnosprawności oraz miejsca osób chorych i osób z niepełnosprawnością we współczesnym społeczeństwie, przede wszystkim należy dokonać analizy antropologicznych założeń uprawianej przez nią pedagogiki. Jest to pedagogika w pełni personalistyczna - osoba postrzegana jest w niej jako wartość samoistna, wobec której nie należy formułować żadnych warunków jej akceptacji, lecz przyjmować ją jako dobro dla niej samej (Kukołowicz, 1970, s. 36; Kukołowicz, 1973). Ta akceptacja ma miejsce przede wszystkim w rodzinie - to tam dziecko nabywa podstawowe poczucie bezpieczeństwa, a relacje $\mathrm{z}$ najbliższymi osobami (osobami znaczącymi, significant others, por. Domagała-Zyśk, 2004) - ojcem, matką, rodzeństwem i dziadkami - stanowią podstawę kształtowania się późniejszych relacji $\mathrm{z}$ osobami spoza rodziny. Istotnymi wymiarami wspierających relacji rodzinnych jest przede wszystkim bliskość fizyczna - najbardziej potrzebna dziecku w najmłodszych latach jego życia, oraz bliskość psychiczna, niezbędna na każdym etapie rozwoju człowieka, a wyrażająca się „optymizmem, spokojem i równowagą" w relacjach (Kukołowicz, 1970, s. 51). Kukołowicz dodaje, że kluczowa w życiu dziecka jest nie tyle stała fizyczna obecność przy dziecku, gdyż ono $\mathrm{z}$ wiekiem potrzebuje coraz więcej przestrzeni dla rozwijania własnej samodzielności i dojrzałości, ile „stała dyspozycja bycia dla kogoś - 
dla jego spraw - nawet najbłahszych kłopotów, radości, pytań i problemów" (Kukołowicz, 2001, s. 198).

Ważnym elementem pedagogiki T. Kukołowicz jest twierdzenie o wyjątkowej mocy wychowawczej rodziny wyrażającej się nie tyle w posiadaniu specjalnego programu, metod i środków (które rodzina także posiada), ile w możliwości realizowania celów wychowania poprzez bezpośrednie spotkanie z innymi osobami tworzącymi rodzinę: „Rodzina jako wspólnota osób, wyrosła z wzajemnej miłości, wychowuje poprzez obecność swoich członków pozostających ze sobą w relacji miłości i życzliwości" (Kukołowicz, 2001, s. 197). W procesie wychowania w rodzinie nie tyle ważny jest słowny przekaz wartości czy norm, ile życie codzienne, wyrażające się w harmonijnym zaspokajaniu potrzeb poszczególnych członków rodziny oraz trosce o inne osoby potrzebujące pomocy. Obserwując zachowania rodziców - to, czemu poświęcają czas, jaka jest ich hierarchia wartości, jaka jest „prawda życia codziennego" rodziny (Kukołowicz 2001, s. 198) - dzieci budują własny świat wartości i norm, które będą drogowskazami w ich życiu.

Jeśli rodzina przyjmuje taki model wzajemnych relacji, jest w niej miejsce dla każdego - zarówno w sytuacjach zdrowia, jak i w sytuacjach choroby i niepełnosprawności. Rodzice i dzieci rozumieją, że takie doświadczenia wymagają właśnie „stałej dyspozycji, optymizmu, spokoju i równowagi” wobec tej osoby z rodziny, która jest doświadczona chorobą czy niepełną sprawnością. Niezależnie od tego, czy jest to dziecko, rodzic czy starszy dziadek lub babcia - rodzina odpowiedzialnie i życzliwie przeformułowuje swoje role tak, aby udzielić osobie potrzebującej jak największego wsparcia.

Teresa Kukołowicz w swoich tekstach wspomina także wielokrotnie (np. Kukołowicz, 2001) o konieczności podejmowania działań nie tylko na rzecz dobrostanu własnej rodziny, ale także promieniowania rodzin na otoczenie i troski o wspieranie rodzin $\mathrm{w}$ trudnej sytuacji - a jedną z takich sytuacji jest choroba przewlekła lub niepełnosprawność. Rodziny doświadczone chorobą mają prawo oczekiwać od innych rodzin szacunku i wielorakiego wsparcia zarówno materialnego jak i społecznego oraz emocjonalnego.

\section{CHOROBA JAKO CZYNNIK WARUNKUJĄCY ZMIANY W SYTUACJI SPOŁECZNEJ I RODZINNEJ}

Chorobę i niepełnosprawność można postrzegać w różnych kategoriach, najczęściej jednak jako stan braku pełnego zdrowia, wywołany przez zmiany strukturalne lub funkcjonalne $\mathrm{w}$ organizmie. Szerzej interpretują sytuację 
choroby i niepełnosprawności psycholodzy i pedagodzy, którzy wskazują na uwarunkowania społeczne, które mogą zarówno przyczynić się do powstawania chorób i zaburzeń, jak też modyfikować ich przebieg oraz samopoczucie i dobrostan (well-being) osoby chorej lub niepełnosprawnej.

W stosowanej przez siebie definicji choroby T. Kukołowicz podkreśla, że chorobę można rozumieć dwojako - zarówno jako proces zmian w organizmie, które mogą zostać zbadane i opisane parametrami medycznymi, ale także jako „subiektywne przeżycie osoby chwilowo wyeliminowanej z pełnienia ról społecznych" (Kukołowicz, 1987, s. 388). Choroba jest więc w jej mniemaniu nie tylko stanem biologicznego załamania organizmu, ale zjawiskiem społecznym. Uzasadniając to istotne twierdzenie T. Kukołowicz zauważa, że dzieje się tak z kilku powodów $(1987,398)$ : 1. Objawy choroby są dostrzegane przez innych ludzi i najczęściej nie sposób ich ukryć; 2. Choroba zmienia wzory zachowania między chorym a innymi osobami - człowiek chory przestaje pełnić dotychczasowe role społeczne a zaczyna pełnić role osoby chorej; 3 . Choroba $\mathrm{w}$ istotny sposób zmienia strukturę funkcjonowania rodziny; 4. Przyczyną chorób mogą być różne czynniki społeczne, np. ubóstwo; 5. Leczenie i szybkość procesów zdrowienia uzależnione są od czynników społecznych.

W swoich tekstach T. Kukołowicz (1987, s. 389) zauważa wyraźnie, że wiele chorób ma swoje źródła nie tyle w uwarunkowaniach biologicznych, ile w nieprawidłowym funkcjonowaniu grup społecznych (grupy rodzinnej czy grupy zakładu pracy), w której dana osoba przebywa. Jako szczególne czynniki ryzyka $\mathrm{w}$ rodzinie wymieniane są przez nią zaburzenia $\mathrm{w}$ procesie socjalizacji i komunikowania się oraz konflikty i nieprawidłowe postawy rodzicielskie. W szerszych grupach społecznych za czynniki ryzyka uznawane są przez nią: nadmierna liczba bodźców oraz, odczuwany szczególnie przez mieszkańców miasta, brak więzi społecznej i poczucie izolacji. Część chorób - jej zdaniem - wynika także $\mathrm{z}$ trudności odczuwanych przez osobę w zakresie pełnienia przez nią określonych ról społecznych, zwłaszcza wtedy, kiedy osoba spotyka się z trudnymi wyzwaniami i oczekiwaniami społecznymi (np. matka pełniąca kierownicze stanowisko i wychowująca małe dzieci, dyrektor obejmujący nowe dla niego zadania). Współcześnie tego typu zaburzenia określamy jako psychosomatyczne, a ich mechanizm jest dość dobrze poznany, jednak obserwacje takie, dokonywane ponad 30 lat temu, miały charakter zdecydowanie nowatorski.

Teresa Kukołowicz zauważa, że choroba często pojawia się także w sytuacjach nagłej i nieakceptowanej zmiany w zakresie pełnienia dotychczasowych 
ról społecznych, np. w okresie przechodzenia na emeryturę. Pojawianie się w tym okresie życia człowieka dolegliwości i chorób dotychczas nieobecnych można bezpośrednio łączyć z frustracją, brakiem poczucia bezpieczeństwa i izolacją wywołanymi zmianami w pełnieniu ról społecznych w okresie, kiedy aktywny pracownik staje się nieprzygotowanym do nowej roli emerytem (Kukołowicz, 1987, s. 389).

Zdaniem T. Kukołowicz - pojawienie się choroby w życiu osoby jest nieodmiennie związane z koniecznością przyjęcia nowej roli społecznej - roli człowieka chorego (Kukołowicz, 1977, s. 57; Kukołowicz, 1987, s. 388). Rola ta - jej zdaniem - charakteryzuje się porzuceniem dotychczasowych ról, a nawet oczekiwań i wymagań, oraz pozostawaniem w postawie dyspozycyjności w stosunku do personelu medycznego. T. Kukołowicz zauważa, że rola pacjenta jest wyjątkowo trudna do przyjęcia. Choroba może zniszczyć człowieka, jeśli uniemożliwia mu pełnienie roli, która jest uważana przez niego za cel życia i stanowi przedmiot identyfikacji. Może też w istotny sposób zmienić dotychczasowe funkcjonowanie społeczne danej osoby, co - nawet przy obiektywnie niedużych zmianach chorobowych - może w istotny sposób wpłynąć na kondycję psychologiczną człowieka chorego czy niepełnosprawnego.

Dużą uwagę T. Kukołowicz poświęca także społecznym uwarunkowaniom leczenia i rehabilitacji (1987, s. 392-393). Podkreśla, że przy proponowaniu form i metod leczenia należy uwzględniać sytuację społeczną pacjenta, np. miejsce jego zamieszkania czy sytuację rodzinną, ponieważ nie każde zalecenie lekarskie może być przez pacjenta realizowane w jego środowisku rodzinnym czy społecznym (np. ze względu na małe możliwości finansowe czy dużą odległość od placówek służby zdrowia). T. Kukołowicz wskazuje także na społeczne uwarunkowania pozornego braku współpracy z pacjentem, które mogą wynikać nie z jego bezpośredniego buntu czy niechęci do przestrzegania zaleceń medycznych, ale trudności w zakresie społecznego przystosowania się do warunków panujących na oddziale szpitalnym, np. innego rytmu dnia, innych zwyczajów żywieniowych, odmiennego, nieznanego pacjentowi sposobu komunikowania się, czy też pojmowania choroby jako sytuacji bardziej korzystnej społecznie - dającej profity finansowe (np. w postaci renty czy świadczeń) lub też zaspokajającej potrzebę zainteresowania i troski ze strony najbliższych.

Analizując społeczną sytuację osoby chorej T. Kukołowicz zauważa, że człowiek chory, przebywający w szpitalu, staje się automatycznie członkiem tej wtórnej grupy społecznej, jednocześnie ulegają ograniczeniu jego kontakty 
z grupą pierwotną - rodziną i grupami, w których funkcjonował przed rozpoznaniem choroby (środowisko pracy, środowisko sąsiedzkie). Ta zmiana najczęściej zaburza poczucie bezpieczeństwa i przynależności, rodzi frustracje (Kukołowicz, 1987, s. 400). Jest ona tym większa, kiedy osoba chora zdaje sobie sprawę, ze choroba uniemożliwi jej powrót do pełnienia dotychczasowych ról, zarówno rodzinnych (np. rola żywiciela rodziny) lub zawodowych (np. pacjent po poważnym udarze czy zawale serca musi liczyć się $\mathrm{z}$ odejściem z dotychczasowego stanowiska, a nawet zakończeniem pracy zawodowej). W takich sytuacjach - zdaniem T. Kukołowicz - potrzebne jest nie tylko leczenie o charakterze medycznym, ale także psychoterapia i socjoterapia uaktywniająca, w której można wykorzystać proste techniki wsparcia, np. rozmowy wspierające, proponowanie chorym zadania udzielania wsparcia osobom ciężej poszkodowanym czy umożliwianie udziału w naradach i spotkaniach personelu, tak, aby pacjent czuł się osobą współdecydującą o przebiegu swojego leczenia (Kukołowicz, 1987, s. 400). Przytaczane przez T. Kukołowicz badania Z. Kawczyńskiej-Butrym (Kukołowicz, 1987, s. 415, za: Z. Kawczyńska-Butrym, 1984) dostarczają informacji, że pacjenci w szpitalach zgłaszają nie tylko potrzeby fachowej opieki i wparcia medycznego, ale manifestują także potrzeby pozamedyczne - doznawania szacunku, życzliwości, zrozumienia oraz potrzebę informacji.

Analizując społeczną strukturę oddziału szpitalnego T. Kukołowicz zauważa, że dobre poznanie potrzeb pacjenta oznacza także poznanie roli społecznej, jaką przyjmuje on na oddziale. Analizując sytuację dzieci jednego z oddziałów reumatologicznych wskazuje, że także wśród pacjentów pojawia się hierarchiczna struktura społeczna - bardziej cenione są dzieci lżej chore, umiejące ciekawie opowiadać, koleżeńskie i mające twórcze pomysły na rozmaite zabawy w ograniczonej przestrzeni oddziału szpitalnego. Takie cechy pozwalają im zająć wyższą pozycję społeczną wśród grupy chorych rówieśników, a tym samym zaspokoić potrzebę uznania i podnieść poczucie własnej wartości. W grupach pacjentów pojawią się także osoby izolowane i nielubiane, co z kolei stanowi dla nich kolejny - oprócz choroby - czynnik złego samopoczucia i frustracji. Rozpoznanie przez pedagoga czy pielęgniarkę rodzaju relacji między pacjentami stwarza szansę na wykorzystanie tej wiedzy dla dobra pacjenta - np. można zasugerować zmianę sali czy też zaproponować pełnienie funkcji podnoszącej pozycję społeczną danego chorego (dzieci np. mogą pełnić rolę pomocnika pielęgniarki, bibliotekarza lub dyżurnego).

Świadomość tych mechanizmów społecznych prowadzi T. Kukołowicz do stwierdzenia o wyjątkowej roli pielęgniarki i pedagoga leczniczego na od- 
działach szpitalnych (Kukołowicz, 1987; por. też Domagała-Zyśk, 1996). Ich rola nie jest ograniczona tylko do działań stricte medycznych (pielęgniarka) czy dydaktycznych (pedagog), ale obejmuje szersze działania udzielania wsparcia społecznego i wsparcia emocjonalnego pacjentom (zwłaszcza dzieciom i młodzieży), którzy znajdują się w tej nowej dla siebie roli.

\section{SYTUACJA SPOŁECZNA I POTRZEBA WSPARCIA RODZINY Z OSOBĄ CHORĄ I OSOBĄ Z NIEPEŁNOSPRAWNOŚCIĄ}

Innowacyjność podejścia, prezentowanego przez T. Kukołowicz, polega na ukazywaniu wpływu choroby na funkcjonowanie systemu rodzinnego pacjenta. Sytuację choroby T. Kukołowicz (1977) rozpatruje zawsze w perspektywie rodzinnej, a analizując sytuację osoby z chorobą przewlekłą lub niepełnosprawnością wskazuje na fakt, że nie tylko ona, ale cała jej rodzina wymaga „troski, pomocy i opieki” (Kukołowicz, 1977, s. 58). Rodzaj tego wsparcia zależny jest od tego, kim jest osoba chora w rodzinie. W sytuacji choroby dziecka często potrzebne jest wsparcie w zakresie organizacji opieki nad nim, ale także pomocy psychologicznej i duszpasterskiej, aby móc poradzić sobie z zadaniem wspierania chorego członka rodziny tak, aby rodzina nie tylko dobrze wypełniała swoje obowiązki wobec osoby chorej, ale także właściwie przeżywała doświadczenie, jakie daje choroba. Kiedy chora jest matka - rozpoczęcie jej intensywnego leczenia wiąże się z koniecznością zmiany modelu opieki nad dziećmi i przejęcia zadań matki przez inne osoby. W sytuacji choroby osoby starszej T. Kukołowicz dostrzega potrzebę oddziaływań psychoterapeutycznych, przygotowujących tę osobę do zasadniczych zmian w zakresie pełnienia ról społecznych - zakończenia pracy zawodowej, przyjęcia drugoplanowej roli w życiu dzieci, które zakładają własne rodziny, konieczności zmiany organizacji rytmu dnia.

W każdej z powyższych sytuacji T. Kukołowicz określa osobę chorą czy osobę z niepełnosprawnością jako pełnoprawnego członka rodziny, a zadania udzielania wsparcia społecznego i emocjonalnego niezbędne do procesu zdrowienia lub akceptacji stanu ograniczonej sprawności powinny podjąć przede wszystkim osoby $\mathrm{z}$ najbliższej rodziny. Także $\mathrm{w}$ sytuacji starości właściwy - jej zdaniem - model relacji rodzinnych zakłada podjęcie przez dzieci i wnuki opieki nad osobami starszymi. Rolą profesjonalisty - lekarza, pielęgniarki czy pedagoga - jest w takiej sytuacji udzielanie wsparcia informacyjnego i społecznego nie tylko pacjentowi, ale także „wspieranie wspie- 
rającego", zgodnie z zaleceniami paradygmatów pedagogiki specjalnej sformułowanych przez I. Obuchowską (Obuchowska, 1987).

Jako przedmiot opieki nad rodziną i osobą chorą T. Kukołowicz (1977) wskazuje „kształtowanie pozytywnego stosunku do choroby, cierpienia i śmierci”. Choroba i niepełnosprawność (np. dziadków w rodzinie) są - jej zdaniem - ważnym elementem kształtującym życie rodziny i nie powinny być postrzegane tylko w kategoriach trudnego doświadczenia, ale także jako okazja do wzrostu osobowego, zarówno dla samej osoby dotkniętej tym doświadczeniem, ale także dla innych osób - szczególnie dla wychowujących się w rodzinie dzieci i młodzieży. T. Kukołowicz (1977) zauważa, że wobec choroby człowiek może przyjąć różne postawy - od całkowitego zaprzeczania jej objawom, poprzez lęk, smutek, frustrację, wycofanie, rezygnację czy wręcz agresję, do postaw pozytywnych - akceptacji i takiej modyfikacji celów życiowych, aby móc je realizować pomimo zmienionej sytuacji życiowej. Taką postawę uznaje za godną naśladowania i wskazuje, że sytuacja choroby może być dla pacjenta i jego rodziny także okazją do wzrostu osobowego i duchowego. Sytuacja choroby i niepełnosprawności jest też sytuacją wychowawczą dla dzieci i młodzieży - wskazuje na różnorodność losów życiowych i ukazuje wzorce zachowania w tej sytuacji - zarówno osoby chorej, jak i opiekujących się nią dorosłych. T. Kukołowicz traktuje chorobę i niepełnosprawność jako nieodłączne elementy „codzienności życia rodzinnego" i okazję do wychowywania młodego pokolenia nie tyle przez formalny program wychowawczy - ile obserwację zachowań dorosłych, którzy są dla dzieci i młodzieży modelami ich własnych przyszłych zachowań.

\section{ZAKOŃCZENIE}

Tak jak wspomniano w początkowej części tego artykułu, poglądy T. Kukołowicz dotyczące funkcjonowania człowieka z chorobą przewlekłą i niepełnosprawnością wyprzedzały epokę, w której były prezentowane. Społeczny model niepełnosprawności został bowiem zaproponowany przez Mike'a Oliviera dopiero w roku 1983 (Olivier, 1990). Zakłada się w nim, że choroba i niepełnosprawność są zjawiskami społecznymi, a ich przeżywanie i sposoby radzenia sobie zależą nie tylko od medycznej kondycji osoby, ale także czynników społecznych - istnienia bądź nie barier i przeszkód w realizowaniu własnych planów życiowych, zakresu i jakości wsparcia informacyjnego, rzeczowego i emocjonalnego doznawanego ze strony osób najbliższych, 
a także postaw i stereotypów prezentowanych $\mathrm{w}$ danym społeczeństwie. W kolejnych latach rozwinięto ideę zależności między doświadczaniem choroby i niepełnosprawności a szeregiem czynników osobowych, medycznych i społecznych, co doprowadziło do sformułowania przez Światową Organizację Zdrowia bio-psycho-społecznego modelu niepełnosprawności, w którym funkcjonowanie osoby jest analizowane w złożonym kontekście interakcji między stanem zdrowia a czynnikami środowiskowymi i osobowymi, między którymi zachodzą dynamiczne relacje (ICF, 2001, 19). Współcześnie w ramach tego modelu - prowadzone są zarówno badania naukowe jak i praktyczne działania diagnostyczne, medyczne, rehabilitacyjne i wspierające funkcjonowanie osób z chorobami i niepełnosprawnościami.

Jak wskazują analizy przedstawione w niniejszym tekście, ideę tego modelu można także dostrzec w pismach Profesor Teresy Kukołowicz, która opisywała jego mechanizm znacznie wcześniej, zanim trafił on do światowej literatury naukowej i stał się powszechnie znany.

\section{BIBLIOGRAFIA}

BogucKa, J. (red.) (1996). Wychowanie i nauczanie integracyjne. Nowe doświadczenia. Warszawa: Centrum Metodyczne Pomocy Psychologiczno-Pedagogicznej MEN.

BYRA, S. (2011). Zasoby osobiste w chorobach psychosomatycznych. Wyd. II poprawione i uzupełnione. Lublin: Wyd. UMCS (ss. 260) (współautor J. Kirenko).

BYRA, S. (2017). Potraumatyczny wzrost i deprecjacja w kontekście nabycia trwałej niepełnosprawności ruchowej. Niepetnosprawność - zagadnienia, problemy, rozwiąania, II (23), 69-91.

DomagaŁA-ZYśK, E. (2004). Autonomia czy odtaczenie? O roli osób znaczacych $w$ życiu młodzieży z trudnościami w nauce (ss. 272). Lublin: Towarzystwo Naukowe KUL.

DomAGAŁA-ZYŚK, E. (red.) (2012). Uczeń ze specjalnymi potrzebami edukacyjnymi w środowisku rówieśniczym (ss. 194). Lublin: Wydawnictwo KUL.

DomagaŁa-ZyŚK, E. (1996). Działania zapewniajace prawidłowy rozwój i wychowanie dziecka hospitalizowanego. Praca magisterska napisana na seminarium prof. dr hab. T. Kukołowicz w Instytucie Pedagogiki KUL

DomaGAŁA-Zyśk, E. (2019). Rodzina w procesie wspierania rozwoju kompetencji społeczno-emocjonalnych dzieci z chorobami przewlekłymi. W: B. SzLuz, Doświadczanie choroby w rodzinie (s. 55-67). Rzeszów: Wydawnictwo URz.

Domagala-Zyśs, E., KNOPIK, T. (2020). Functional diagnosis as a strategy for implementing inclusive education in Poland. Revista Brasileira de Educação Especial, 26(2), 203-330.

ICF - Miedzynarodowa Klasyfikacja Funkcjonowania, Niepełnosprawnosci i Zdrowia. (2001). Geneva: WHO. Wydanie polskie: Centrum Systemów Informacyjnych Ochrony Zdrowia (2009).

KAWCZYŃSKA-ButryM, Z. (1984). Rodzinne aspekty choroby. W: T. KuKOŁowicZ (red.). Z badań nad rodzina (s. 59-166). Lublin: Redakcja Wydawnictw KUL. 
KAWCZYŃSKA-BUtRYM, Z. (1992). Problemy pacjenta w podstawowej opiece zdrowotnej. W: T. KukoŁowicz (red.) (1992). Pielęgniarka - pacjent. Nowe modele opieki i pielęgnowania (s. 15-25). Stalowa Wola: KUL, Filia WNS w Stalowej Woli.

KaZANowski, Z. (2011). Przemiany pokoleniowe postaw wobec osób upośledzonych umystowo. Lublin: Wydawnictwo UMCS.

KIRENKO, J. (2007). Indywidualna i spoteczna percepcja niepetnosprawności. Lublin: Wydawnictwo UMCS

KukoŁowicz, T. (1970). Akceptacja dziecka w rodzinie. Zagadnienia wychowawcze a zdrowie psychiczne, 4(5), 35-45.

KukoŁowicz, T. (1973). Poczucie bezpieczeństwa w rodzinie. Zeszyty Naukowe KUL, 1(48), 49-62.

KukoŁowicz, T. (1977). Chory w domu i opieka nad nim. Śląskie Studia Historyczno-Teologiczne, 12, 57-60.

KukoŁowicz, T. (1987). Wybrane zagadnienia z socjologii. W: Z. PutKIEwicz, B. Dobrowolska, T. KuKoŁowicz. Podstawy psychologii, pedagogiki i socjologii. Podręcznik dla średnich szkót medycznych (s. 334-379). Warszawa: PZWL.

KukoŁowicz, T. (red.) (1992). Pielęgniarka-pacjent. Nowe modele opieki i pielegnowania. Stalowa Wola: KUL, Filia WNS w Stalowej Woli.

OBUCHOWSKA, I. (1987). Obecne i nieobecne paradygmaty w pedagogice specjalnej. Kwartalnik Pedagogiczny, 4, 12-16.

Oliver, M. (1990). The politics of disablement. London: Macmillan Education.

OGIŃSKA-BULIK, N., JUCZYŃSKI, Z. (2010). Rozwój potraumatyczny - charakterystyka i pomiar. Psychiatria, 7(4).

Parczewska, T. (2012). Doświadczanie koleżeństwa i przyjaźni przez dzieci z chorobami przewlektymi. Lublin: Wydawnictwo UMCS.

Putkiewicz, Z., Dobrowolska, B., KukoŁowicz, T. (1987). Podstawy psychologii, pedagogiki i socjologii. Podręcznik dla średnich szkót medycznych. Warszawa: PZWL.

RIESER, R. (2012). Implementing Inclusive Education. A Commonwealth Guide to Implementing Article 24 of the UN Convention on the Rights of Persons with Disabilities. London: Commonwealth Secretariat.

SokoŁowska, M. (1986). Socjologia medycyny. Warszawa: PZWL.

\section{OSOBA CHORA I OSOBA Z NIEPEŁNOSPRAWNOŚCIĄ W RODZINIE W UJĘCIU TERESY KUKOŁOWICZ}

\section{STRESZCZENIE}

Profesor Teresa Kukołowicz (1928-2014) pracowała w KUL w latach 1959-2001, prowadząc m.in. nowatorskie badania $\mathrm{w}$ zakresie socjologii medycyny oraz pedagogiki leczniczej.

Artykuł obejmuje analizę pięciu tekstów T. Kukołowicz, w których przedstawia ona autorskie, oryginalne rozumienie osobowych, psychicznych i społecznych uwarunkowań funkcjonowania osoby chorej, zwłaszcza w aspekcie zmiany ról społecznych związanych z chorobą i niepełnosprawnością, uwarunkowań pełnienia „roli człowieka chorego”, rodzinnych kontekstów chorowania oraz znaczenia choroby i niepełnosprawności jako istotnego czynnika rozwoju osobowego, w tym szczególnie rozwoju duchowego. Wnioski prowadzą do stwierdzenia, że prezen- 
towane przez T. Kukołowicz poglądy były nowatorskie i może ona być postrzegana jako prekursorka bio-psycho-społecznego modelu niepełnosprawności i choroby. Jej pisma zawierają także szereg intuicji, które warto rozwijać we współczesnej pedagogice leczniczej.

Słowa kluczowe: Teresa Kukołowicz; choroba; niepełnosprawność; pedagogika lecznicza; KUL; człowiek chory.

\section{A SICK OR A DISABLED PERSON IN THE FAMILY: A VIEW PRESENTED BY TERESA KUKOLOWICZ}

\section{SUMMARY}

Professor Teresa Kukołowicz (1928-2014) worked at the Catholic University of Lublin from 1959 to 2001, pursuing, among other things, innovative research in sociology of medicine and therapeutic pedagogy.

The article explores five texts by Teresa Kukołowicz which present her original understanding of personal, psychological and social conditioning of how a sick person functions, especially in respect of changed social roles associated with sickness and disability; factors conditioning the role of a "sick person", various family contexts of being ill, and the meaning of illness and disability as factors significant for personal and especially spiritual growth. The conclusions imply that the views presented by Kukołowicz were novel and that she may be perceived as a forerunner of the bio-psycho-social model of disability and illness. Here writings also contain a numer of intuitions which are worth pursuing in contemporary therapeutic pedagogy.

Keywords: Teresa Kukołowicz; sickness; disability; therapeutic pedagogy; KUL; a sick person. 